\title{
Paper, Perception and...Facts? \\ Exploring Archaeological Heritage Management in the Mediterranean and the Weight of Public Archaeology
}

\author{
Jaime Almansa-Sánchez \\ Institute of Heritage Sciences, CSIC (Spain)
}

\begin{abstract}
\#pubarchMED is a project aiming to define the dynamics of archaeological heritage management in the Mediterranean from the perspective of public archaeology. Its ethnographic approach draws on three main sources: legal and academic literature, observation and the perception of professionals. This paper aims to delve into the development of public archaeology and how it impacts practice across the Mediterranean. While the importance of contemporary society for archaeologists seems to be high in the interviews conducted, it will be discussed to what level current practice actually deals with these issues in a critique of a traditional approach to archaeology that does not recognize the transversality of public archaeology or its importance for the future of the discipline itself.
\end{abstract}

\section{Keywords}

Mediterranean; public archaeology; archaeological heritage management; perception; pubarchMED

Introduction: \#pubarchMED and the need to look beyond the stones

Public Archaeology in the Mediterranean Context (\#pubarchMED) is a three and a half years' project funded by the Galician Research Agency (GAIN) and conducted from the Institute of Heritage Sciences of the Spanish National Research Council (Incipit, CSIC). Its main goal is to better understand the dynamics around archaeological heritage management in the Mediterranean basin, with a focus on public archaeology and our impact on people.

In order to do so, the project is divided in three main lines of research: 1) Bibliography. Aiming to record a database of references from the region that shows the high amount of literature in the field. It involves a traditional literature review but goes 
beyond the mere collection of references and aims to recognize the potential of Mediterranean practice in a global context dominated by English-speaking institutions and trends. A first version of the database is already available (AlmansaSánchez 2020a) and it is now open for collaborative completion. 2) Perception. Aiming to understand the management of archaeological heritage in each of the 32 countries included in the project, from the perspective of professionals from different spaces in the process and at different stages of their careers. I will delve on this in the next section. 3) Impact. Aiming to explore the actual consequences of archaeology for local communities living in the surroundings of a site. Problematising current trends about economic impact, I am developing a methodology to measure impact from other perspectives. The large variability in the typology of sites and contexts made it difficult to standardize the method, but the results seem interesting and will be subject of other publications. This article will focus on one of the lines, perception, but feeds from the other two too. Therefore, it aims to reflect on the flaws of current practice regarding the implementation of public archaeology strategies-from the public management point of view. While academic work on the topic is extensive, knowledge transfer to the public sector is limited.

One of the main challenges of the project has been fieldwork, especially after the burst of the Covid-19 pandemic. Thirty-two countries were included, and visits needed to be made (Fig. 1). Beyond the Carbon footprint of the project, that has been compensated, the logistics of this work, with no specific budget for travelling, were complicated. The disruption of the pandemic forced me to design a virtual alternative that did not work satisfactorily, among other troubling consequences (Almansa-Sánchez forthcoming).

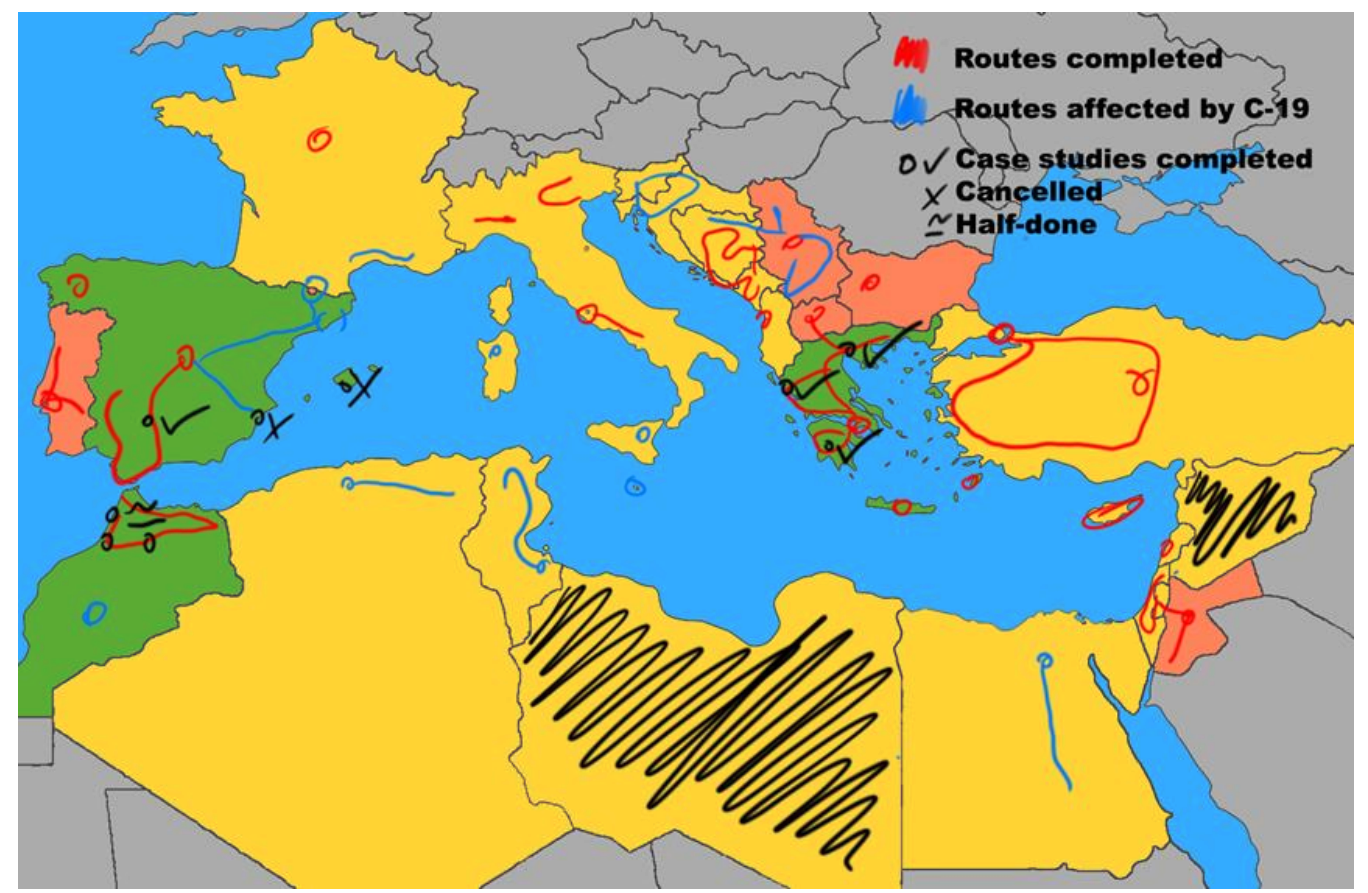

Figure 1. Map of the Mediterranean basin with the countries studied and the field visits. In yellow, the countries that face directly the Mediterranean; in red, those that do not face the Mediterranean, but I included as part of the regional influence; in green, the three countries selected for the "impact" case studies. Notes show the impact of the pandemic. The handwritten notes show fieldwork conducted (red) and aborted by the pandemic (blue), in which case a digital alternative was tried. 
The philosophy of the project builds on the idea that public archaeology needs to be a transversal issue in archaeological practice beyond Academia but, as of today, the main focus is on the remains of the past with little worry about the consequences of our work in the present. We trust the positive public image of archaeology (e.g. Marx, Nurra \& Salas-Rossenbach 2017) without question, put the conservation of the remains before any other interests and disown any responsibility for the possible consequences. However, the public image of archaeology is usually distorted by the romantic view of the past, in the sense of the archaeoappeal defined by Holtorf (2005) and this affects some other preconceptions about values and attitudes towards heritage.

The idea of public archaeology amongst other colleagues focuses mainly on direct engagement and participation (Richardson \& Almansa-Sánchez 2015), which are important but miss other facets of the discipline like those defined by Moshenska (2017: 5-11). Without advancing in those other "types" of public archaeology, I believe we will fail in our efforts to improve archaeological practice.

This is why one of my main concerns for this project was to focus on the perception of professionals, as the technical view of our practice overtakes some important structural dynamics that are essential for a better understanding of archaeology. From internal conflicts to inefficient protocols, we need to improve our own knowledge of the archaeological ecosystem, a concept defined by my colleagues Marta Cuesta and Ángel Astorqui for a project to cohesion the collective that took place in Spain during 2019-2020. It implies the different actors involved in archaeological practice in all their complexity. This comprises the different spaces in which the archaeological process happens: administrations, museums, universities and research centers, for profit and non-profit private organizations, individual researches, etc.; as well as the complexity of tasks involved. Indeed, some preliminary observations about the interviews undertaken show how a vast majority of the colleagues interviewed have a very good knowledge of their own space of practice, but very limited and stereotyped views of other spaces that are not part of their daily routine. But let's start from the beginning.

\section{On methodology}

When considering how to approach the definition of archaeological heritage management models we have an easy way from the literature. Laws and further policies are mostly available online, and there are some exploratory works in the literature that delve into some specific topics. However, there were two reasons why I did not want to follow (only) that path. First of all, the disproportion of information among countries that made some like Spain, France or Italy very well known, while others, especially the smaller or newer ones, were almost unknown. Also, the experience from my $\mathrm{PhD}$ research (Almansa-Sánchez 2017) shown how most published views are partial (incomplete and biased), and regulations suffer from a deep problem of arbitrariness in the interpretation. Eliminating those biases was not an easy task, but ethnography and philosophy usually help. 
José Ortega y Gasset was a Spanish well known intellectual that carried out a proposition on Perspectivism that seemed adequate to articulate the project. Feeding from previous thoughts by Leibniz or Nietzsche (De Salas 1994), Ortega y Gasset (1914) builds his reasoning on the embracement of subjectivity under the premise that an individual's perception of a reality is as real as any other but is shaped by the specific reality (circumstance) of the individual. Then, only the sum of different individual perspectives understood in their personal circumstances can offer a clearer picture of such reality. Therefore, by collecting these different views on the same aspect, the final description can be more complete. This would be similar to the collection of images for a photogrammetric interpretation of an archaeological entity. However, we would still need to process these images and create the final outcome. Here, Critical Theory becomes essential.

Quite trendy in the USA during the 1980s and 1990s, mainly thanks to the works in Annapolis (Potter 1994), Critical Theory went unnoticed for archaeology, probably due to the difficulties of building an interpretative framework around it. However, this is probably its best quality when aiming for a critical analysis of our contemporary reality, as self-consciousness, anti-positivism, the focus on the particular and a close relation between theory and praxis (its main characteristics) are essential to disentangle the multiple contradictions of our daily practice. Indeed, I also define public archaeology as a critical theory of archaeology (Almansa-Sánchez 2017), as disentangling the multiple relations between archaeological practice and the contemporary world meets the same aims. Nevertheless, this perspective plays an important role in the analysis of the different discourses affecting the project, in line with Critical Discourse Analysis (Fairclough 2003).

But which are these discourses? I already mentioned the literature but wanted to focus on two other resources: visits and interviews. The first one is probably the more subjective of both, as it falls into a direct personal interpretation of my experience in archaeological sites and museums. I have tried to use it only to double check some of the statements during the interviews, but it is impossible to avoid creating a new discourse from this experience in line with Debord's drift and psychogeography (Debord 1956). This could be described as my own perception of the reality, shaped by a critical observation and listening of the official discourse in archaeological spaces and the personal perspectives of the interviewees. In this sense, interviews are probably the main source of information (and sometimes disinformation too) and became a central part of the project.

I designed a semi structured questionnaire, tested with five colleagues. It had two types of questions; closed (answered in a word or a sentence) and open (conversational or descriptive). It was designed not only to gather specific data, but also to explore reactions and build confidence. Most of the people interviewed were unknown to me before the interview, and I was aware of my disruptive presence (and questions). It started with two ice-breaking questions (define archaeology in one word; and public archaeology) to continue with a first description of the archaeological ecosystem in their country. I preferred a general overview, but sometimes I focused only on their specific space due to an already large number of interviews or the evident lack of awareness about other spaces. It usually took some 
more specific questions to delve into certain aspects as part of the conversation. Then, new short questions about priorities and challenges to go for one of the main blocks: Three aspects to change and three to keep. This was probably one of the more interesting responses in the questionnaire and usually denoted trust (if by this moment the interviewee seemed "closed" there was no sense in insisting). Finally, I focused on the concept of public, their participation in the model, and an evaluation of the general picture. A last question tried to gather other stereotypes within the collective asking for three icons (sites, people, institutions, artefacts) of archaeology in their respective countries, showing sometimes very interesting views and preferences. The conversational side of the interview was probably the most interesting side of this approach, as it allowed to uncover a lot of details.

All interviewees had to sign a consent for the interview and the recording (if they let it happen), as well as choosing between a fully anonymous interview or the possibility to use their names for reference. I found this last part important, as sometimes their comments are very interesting, and I have no intention to appropriate those ideas without a clear reference. One hundred and fifty seven interviews have been made (still processing them), and the results will be available in open access in the repository of the Spanish National Research Council (CSIC) ${ }^{1}$. As commented before, Covid-19 has been disruptive for fieldwork, not only for visiting sites, but also for the interviews (Almansa-Sánchez forthcoming). During the first weeks of lockdown I waited, uncertain about the future and cancelling trips. Once it was clear the impact would last months, I started to design digital alternatives. Mainly tried: video calls, audio calls and emails. None of them were comparable with the in-person experience and I am quite upset about it because, although I could gather some interesting information from some countries (Monaco, France, Eslovenia, Croatia, Egypt, Libya or Tunisia), some others remained either obscure or very underrepresented. The case of Algeria (first trip cancelled due to the lockdown) and Morocco (with three weeks of fieldwork cancelled after months of waiting for the borders to open) were especially difficult, as no interviews were completed. For the 21 online interviews conducted over one hundred emails were sent. Furthermore, the information obtained from the digital alternative was not as rich or complete and I am not happy with more than three or four interviews during the Covid-19 disruption.

Still, the ethnographic approach (Hamilakis \& Anagnostopoulos 2009) has proved to be optimal for this kind of project and the combination of information from different sources will offer data and reflection for a long time. For the moment I would like to focus on some preliminary (or general) thoughts on the integration of public archaeology within the different management models we have in the Mediterranean basin.

\footnotetext{
1 They can be found here: https://digital.csic.es/cris/project/pj00216
} 


\section{Public archaeology in the Mediterranean from the perspective of \#pubarchMED}

The Mediterranean is complicated like most regions in this World. There are some different areas with different traditions and a very rich history that shapes certain details and realities. I already made a very short introduction in a previous article (Almansa-Sánchez 2020b), so will not reproduce it here. But we need to be aware about this complexity in order to understand some general statements.

Regarding the management models, I am defining a scale that places models between two extremes: a Public Model (ideally conducting all management in public institutions), and a Private Model (ideally doing so in private institution). A quick look at the general situations shows that there are not pure models, as there is always some sort of mix. They just tend to one or the other or stay in the middle ground. A more in depth look at the models shows that there are not two equals in the Mediterranean and each one has some distinctive detail that makes this study more interesting. Generally speaking (a more in-depth work will be published on this issue), Mediterranean countries pivot between models slightly tending to private in Western Europe (Italy, Spain, Portugal) due to the presence of commercial archaeology, and models more strongly tending to public in North Africa, Levant and Eastern Europe (although with some caution).

One of the main aims of the project is to define a clearer picture of the different models, but also to find more effective solutions to our challenges in the daily management of archaeological heritage. The wide variety of models and solutions to specific details on the process of management is essential to shape a toolbox of proposals that will come with the completion of the project.

I understand management as the full process from planning to outreach (Martínez \& Querol 1996), and therefore, this falls totally under the scope of public archaeology (Schadla-Hall 1999). Therefore, I want to focus on some specific aspects: 1) the concept. How do professionals in different countries understand public archaeology (and the public); 2) official implementation of outreach policies. Focusing on one of the main and more spread aspects within the discipline; 3) impact. Or how decision-making during management impacts people and the consequences of these dynamics.

The concept of "public" is probably one of the most interesting aspects within the interviews. I try to exploit Matsuda's (2004) approach to the double meaning (people/state), and in many cases, especially in countries with a longer tradition, interviewees brought up this dichotomy. I did not bring up this before, but we have to take into account most interviews were carried out in English, which was not the first language (in some cases not even the second) of the vast majority of colleagues. My personal very basic understanding of some other languages helped in the communication process, but sometimes it created interesting misunderstandings. However, I want to highlight a quite general tendency to simplify the concept. Defining "the public" as "everybody" is one of the most problematic issues in management, as we create a homogenous audience/interlocutor that falls into the flaws of standard design (see Hendren 2020). The complexity of communities, 
interests and interactions is vast and we still need to do a great deal of research on this side.

This relates directly with the implementation of official (and unofficial) outreach programs. For the majority of interviewees, this is probably one of the weakest aspects of management and is still mainly restricted to educational programs in museums. Some research projects (still a minority) have developed some sort of action in the last couple of decades, and very few legislations offer clear mandates in this sense. The differences between countries are enormous, but the assessment of the situation is quite homogenous. We are not doing enough. Here, it becomes complicated to define what we can consider as active outreach beyond the basics of "showing". Having a museum or archaeological site open to the public is not considered as such from my perspective (they are the most basic "musts"), nor the mere existence of some basic interpretation materials like panels or guides (when they even exist). Indeed, the lack or quality of interpretation in many archaeological spaces is a problem of its own, and some integration solutions from preventive/rescue archaeology lack any visibility, maintenance or sense (Fig. 2). There is a growing literature about innovative case studies with different technologies and techniques. However, most sites worldwide are still underinterpreted and rely on tourist guides or internet (unofficial) resources. My "expectation" of a step further goes to more interactive activities, social media strategies, public talks, or other creative resources, especially during ongoing archaeological works, without forgetting the already forgotten sites of our rural (and even urban) areas.

All this is not trivial, as the public image of archaeology is forged through multiple experiences and stimuli over a person's life (Almansa-Sánchez 2017: 130) and this may have consequences in decision making, both for heritage and people. Years ago, I wrote a small story (Almansa-Sánchez 2014) about the importance of good heritage education for the future of the discipline from a simple fact. In most countries, decision-making processes on archaeological heritage are affected by many interests and archaeology itself is only one of them. Here is where impact becomes important. There is an extensive literature about the economic return of heritage investments (e.g. Burchi \& del Soldato 2009), and lately some works about well-being and community archaeology (the last, Watson 2021). However, the first is vague enough (from 3 to over 50 euros of return from each euro invested) and the latter, restricted to a tiny percentage of the archaeological activity. When trying to measure the impact of archaeological sites from the project, I realized that the actual impact of most sites was minimum. Major archaeological sites live off of their prestige, and the Mediterranean is a major global center for this. In countries like Italy, Greece, Turkey or Egypt, archaeology represents a structural income for many regions, based principally on tourism. However, current research focuses on the specific audiences and dynamics of a site/region (see journals like Journal of Heritage Tourism, or Pasos) instead of looking at the bigger picture and disentangling the actual lure of archaeology within the global market. Furthermore, the inequality in visitor numbers (and therefore, income) from site to site makes it very difficult to assume a standard economic impact when we do not even have proper macroeconomic studies that 
disentangle this picture. There is no doubt, however, that the potential of specific projects and plans is real (Gould 2018), and that we can move forward towards different values and impacts that also affect positively communities around heritage. We just need to have a closer look.

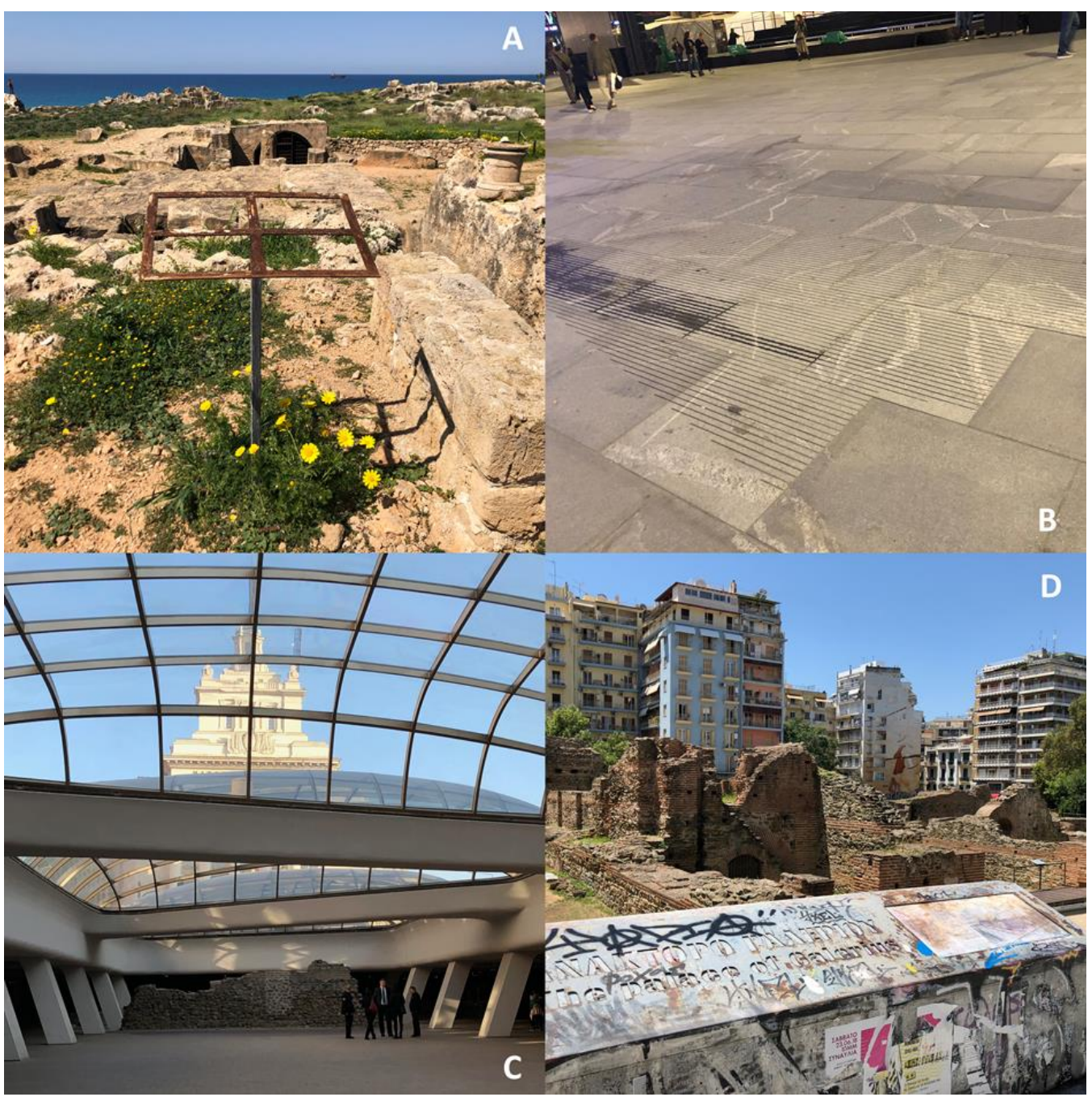

Figure 2. From the vast catalogue I gathered over the years, I would like to share four characteristic examples: a) Tombs of the Kings (Paphos, Cyprus), without panels and old rusty stands; b) Ottoman gate (Belgrade, Serbia), just some fissures on the new pavement following the footprint of the old gate with no related interpretation; c) Old Serdika wall (Sofia, Bulgaria), under the modern structures built during the regeneration of Nezavisimost square (and more in the surroundings), it is a very dynamic public space with little interpretation; d) The palace of Galerius (Thessaloniki, Greece), with all the exterior interpretation vandalized giving a look of abandonment similar to many other lots in the city.

Bringing up some examples from the project (in depth analysis of these case studies will be published in future works and the book of the project), we can see the contrast between cases and the different levels of analysis we can make. In Greece, Ancient Messene and Rotonda were two of the case studies. The first can be considered a success story that affects two small villages around the site (villagers even changed the name of the closest to the one of the site), with some new businesses, a strong engaged community and a clear positive change since the beginning of the works. However, it is just a complement to other jobs in Kalamata 
or agriculture, affecting only a small number of people and while other villages in the surroundings have no impact at all, even a negative one with the strengthening of the main road for proto-mass tourism (incipient growth). Also, the site is still growing by word of mouth, not included in major archaeological routes and embedded in a complex market (Fig. 3). For example, near Costa Navarino, one of the most exclusive resorts in the Mediterranean, the affluence of Russian millionaires has promoted VIP visits to nearby monasteries (with very little local impact) but not to the archaeological site.

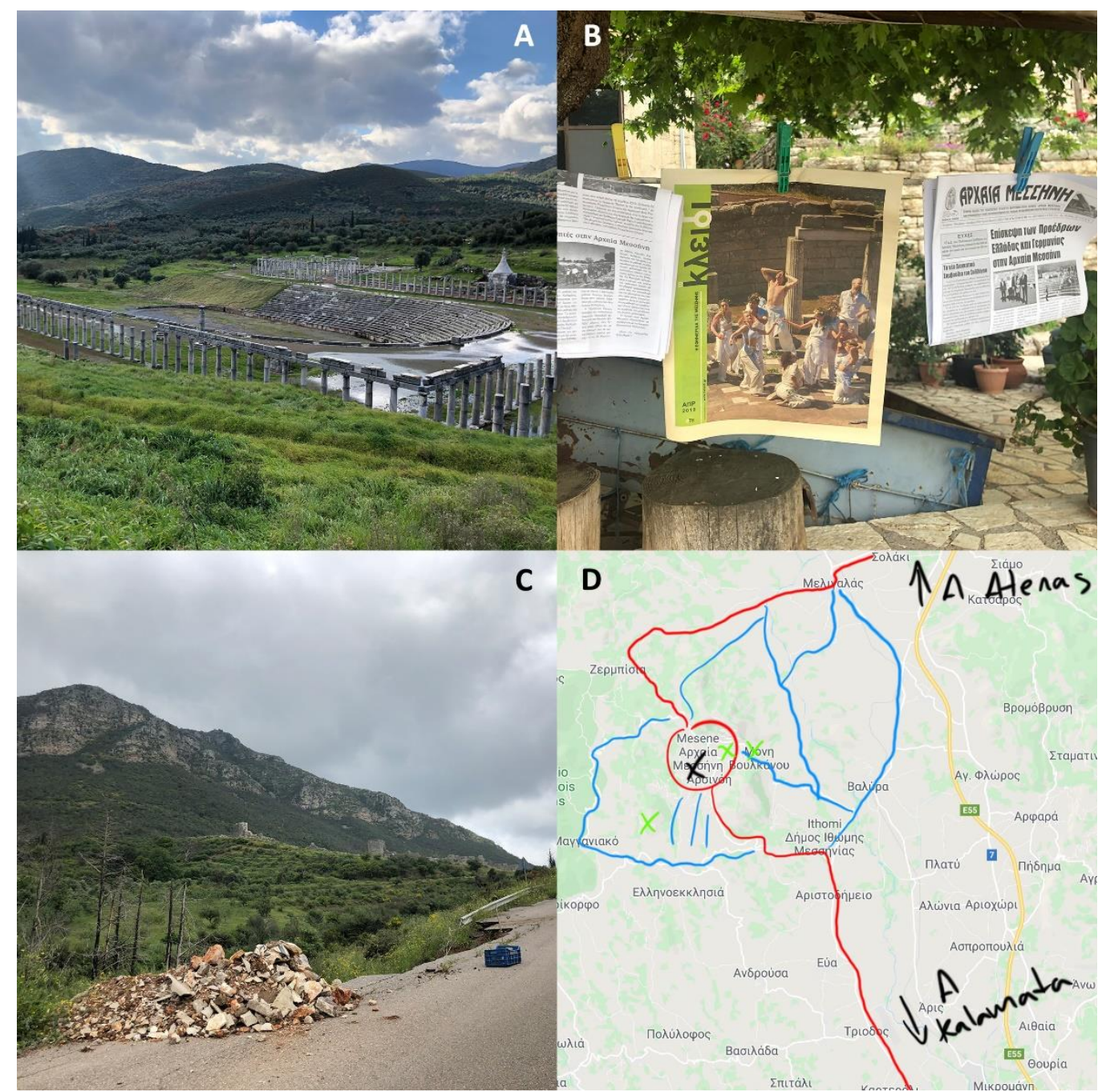

Figure 3. Some images from Ancient Messene: a) A view of the anastylosis of the stadium; b) A local vendor with a copy of the community newspaper named after the site; c) Damaged road towards the site (the main good one goes parallel); d) Field sketch of the surroundings and the roads. In red the main one, that concentrates all the resources of the area.

Rotonda, an impressive monument in Thessaloniki, is part of a World Heritage declaration in the core of the city. Inside the enclosure, it is a success. All activities are always full, conservation is good, it has even become one of the icons in the city, but there are other dynamics outside of it that make it more complicated. A deep 
look at the numbers ${ }^{2}$ shows a very low income in tickets that probably does not cover the expenses; the actual engagement with the local community barely reaches a tiny percentage of the population; and the economic impact is also minimum, being the university the actual driving force of the neighborhood, that is quite impoverished anyway (Fig.4).

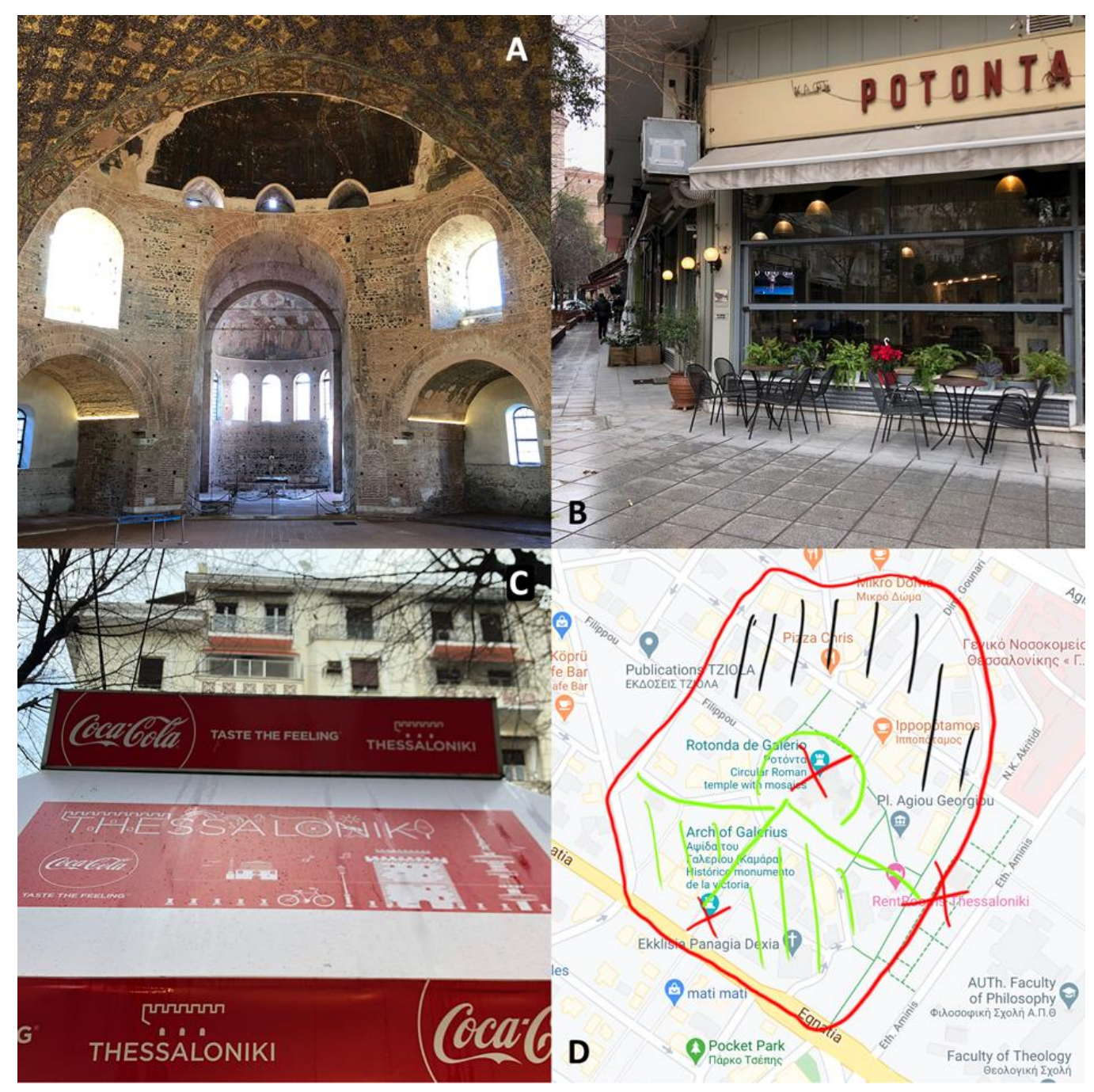

Figure 4. Some images from Rotonda: a) The monument; b) Old bar nearby that took the name (identity) from it; c) Coca-Cola advertisement with the shape of the monument as icon of the city; d) Field sketch of the surrounding blocks and the economic activity. In green, where reprographics and coffee shops concentrate in the southern blocks, close to the main street and the University, while the northern blocks (in black) remain mostly abandoned.

All together we can start to see the importance of deep research about archaeological heritage management from the perspective of public archaeology in order to understand the actual (and complex) dynamics of archaeology in the local environment. The same way stones do not speak, they do not foster growth or culture and identity by themselves. One of the main burdens identified from the interviews has to do with the standardization of formulas that might work for the

\footnotetext{
2 The Greek government (Hellenic Statistical Authority) publishes updated statistics of visits and ticket income: https://www.statistics.gr/en/home (search for "museum" or "archaeology").
} 
Colosseums and Pyramids of the world but leave hundreds of archaeological sites in very precarious conditions, affecting not only their conservation, but also the overall image of archaeology. This is strongly related to the general lack of resources (economic and human) of every administration and the problems in collaboration public-private that we still bear, even in countries with a long tradition of privatizations.

I am focusing mainly on the managerial side of the story, but academic research is not alien to these problems. The interviews also exposed lack of interest or incentives, as well as lack of funding, even for traditional archaeological works. So, we should maybe focus on some of the structural problems of traditional practice instead.

\section{A critique of traditional practice}

What is traditional practice? With such a dynamic and varied discipline as archaeology is, trying to define the "traditional" is problematic and usually leads to misunderstandings. The coming critique does not mean that we should stop excavating, for much I support the increasing call for degrowth (Flexner 2020; Zorzin 2021), but that we need to reconsider priorities and pay attention to the present and the future of our discipline within a progressively more demanding society.

The aforementioned idea of public archaeology as a critical theory of archaeology plays an essential role in this sense. The profession has been so focused on the research and conservation of past remains that often forgets who or why we are doing it for. Within the interviews, most colleagues spoke about the importance of bequeathing all the knowledge and heritage we produce to future generations, about the importance of communicating with (all) the publics and the relevant social work we are doing. There is no doubt that many spaces and projects actually play that role, but a closer look to the structural functioning of the archaeological ecosystem questions it.

We can differentiate levels of practice: first, intervention and management. Intervention would be those works that aim to record and study archaeological heritage, while management refers to the post-intervention processes of conservation and divulgation and the general apparatus that allows and regulates intervention. Here it does not matter whether the initiative is public or private, as most tasks apply to all models. Within "intervention" we have academic and preventive/rescue, but also different types of action that involve different practices (which applies to "management" too). For the moment, I will focus on four of the more relevant complaints during the interviews beyond the structural lack of funding.

Academic discomfort. There is a general feeling that the model of excellence being promoted in Academia is starting to have negative consequences. These complaints are more present in the European side of the Mediterranean, but not only. One of the main aspects is mental health (Evans et al. 2018), recently highlighted but present for a long time now. There are multiple factors that explain it, from toxic 
environments (where maybe harassment represents the higher component [CotoSarmiento et al. 2020; Voss 2021]) to the stress of constant productiveness in order to survive the already narrow perspectives of a future in Academia. The situation itself is of interest for public archaeology, but it also brings up another aspect of the problem. Besides some new calls that openly ask for outreach programs and even participation, the vast majority of non-purely-archaeological work is not only scarce, but discouraged. The lack of academic recognition, the contempt for these types of actions, or the actual difficulty to implement good programs without the proper background or expertise, only hinder a greater presence. This is probably the most paradoxical aspect of the whole project: while identifying a clear support of public archaeology in the vast majority of the profession and a general call for transdisciplinary projects, the results of most calls are still purely archaeological work, maybe with some technological improvements or archaeometric techniques. I generally do not call for only-pubarch projects, but for the inclusion of expert colleagues in teams (and budgets) in the same way we have naturalized samples or topography.

Alienation by record. This is not a new feeling. The development of preventive/rescue archaeology as part of the management environment led to a problematic reality. We have never excavated as much as we have done in the last couple of decades. However, we do not produce a comparative amount of knowledge. The first consequence has to do with grey literature, but also with the design of the models (Olivier 2016). For a moment, we jumped uncritical into the new situation, expecting great opportunities and, in some cases, where the privatization of the service occurred, gaining a good wage and better chances beyond Academia, museums or the administration. A more in-depth exploration of the different models is under the scope of the project and will be subject of further writing, but now I wanted to refer to a feeling not that represented in the interviews (as maybe is not lived by all professionals and is mostly represented in countries with commercial practice), but still important. "Conservation by record" is the main philosophy of preventive/rescue archaeology (Novaković et al. 2016). However, the systematic destruction of excavated remains with unpublished and/or partial reports is not meeting the fundamental goal of archaeology. We have become mere technicians in the construction process instead of better positioned researchers, and materials accumulate in storage with no funds for further research. We need to reconsider the model.

Conservation before people. This is a personal conclusion from a recurrent answer during the interviews. Even considering the importance of a better relationship with society, to the question about priorities, conservation represents the central concern. We give research for granted and forget there is no conservation without caring about people (Pastor-Pérez 2016). This is a position easy to understand under the current circumstances of archaeology. The many threats that affect archaeological heritage (from looting or conflict to climate change) provoke a response of urgency in professionals who deal with this heritage. Under the possibility of losing an asset, we run for some sort of conservation (even if it is by record) and forget about any context or consequence. In this sense, I will not focus on the perversions of 
preventive/rescue archaeology now (see Zorzin 2015), or the abovementioned call for degrowth. On the contrary, I would like to highlight the importance of the consequences and the need to stop and think before making any decision. Some of our actions bring a negative impact for people, and we barely explain the reasons beyond legal mandates or well-known stereotypes. What brings us to the last point. Conflict and communication. When we address conflict, it is usually in the frame of armed conflicts and the destruction of cultural heritage. When we address communication, it is usually about the past or the image of archaeology. Here I would like to focus on a different perspective that focuses on other daily conflicts and the general lack of communication within the collective and beyond. One of the things that the interviews have been able to identify is internal (sometimes structural) conflicts between different spheres of the archaeological ecosystem. Universities versus companies, companies versus administrations, administrations versus the universe, and so forth; we need to better understand each other and the specific situations we suffer. There is an extended feeling of hatred against professionals working in administrations from all sides and some open conflicts in many countries. We lack empathy towards one of the most difficult positions within the archaeological ecosystem, underfunded and understaffed. It is true that irregularities exist, but overall, they do an essential (and unrecognized) work under the permanent pressure of politics. I connect this with the generalized ignorance about the whole model and maybe a more comprehensive knowledge of the archaeological ecosystem would help in this sense. However, some of these micro-conflicts are purely personal and based on different interests. This also applies to the relations with society. The existence of conflicting values and interests create an alternate discourse for and against archaeology, that deserves further study and attention. From clichés like "archaeology stops development" or pseudo-archaeological theories, to more serious uses of the past that would require a deeper analysis (Fig. 5).

This is just a sketch of a large and complicated reality that the project aims to disentangle and analyze in more depth. In general lines, beyond the structural problems that the current economic and political reality shape, and that are of interest for public archaeology too, I wanted to point out some aspects that call for a focus on people and the future in archaeological heritage management. This is not in conflict with conservation or traditional research, but a complementary perspective that we should consider more seriously as time passes. 

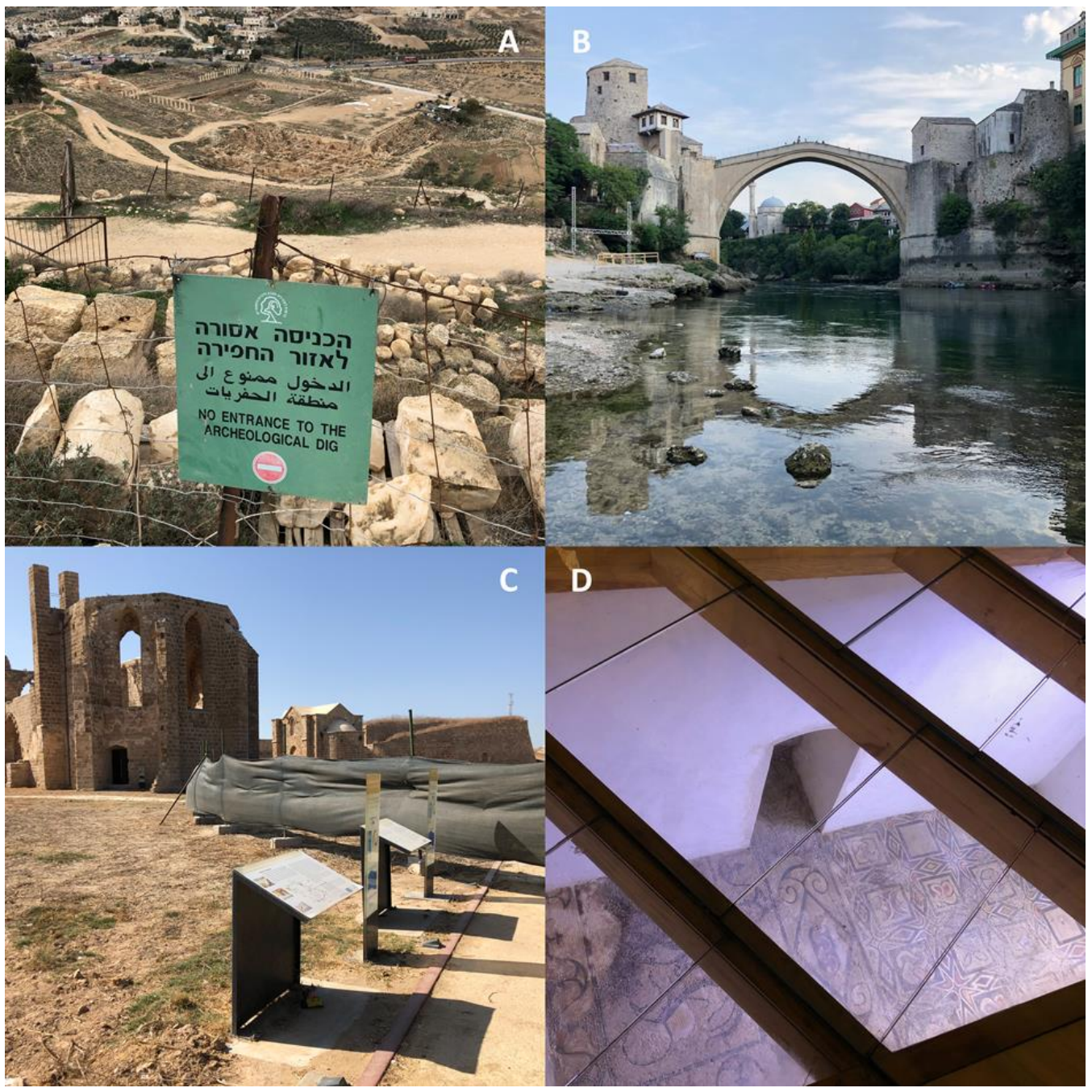

Figure 5. Four examples: a) Herodion (Israel), a National Park in the middle of the West Bank; b) Mostar Bridge (Bosnia and Herzegovina), an icon of conflict and reconciliation (?); c) Christian churches in Famagusta (North Cyprus), and the intervention of the UNDP and the EU during an open conflict; d) Cordoba Mosque-Cathedral (Spain), or the search for the Christian origins of the monument.

\section{Discussion}

A people-centred approach is not new at all, and even international bodies are starting to promote it (Court and Wijesuriya 2015). Not intending to write a short story of public archaeology, before the term came out with McGimsey (1972), there was already a call for relevance in the public sphere (e.g. Fritz and Plog 1970: 412), mainly driven by the thread of losing archaeological heritage. This drive is still in the center of the discourse. This focus (still mainly) on the mere conservation of archaeological heritage acknowledges the possible broader picture of the impact this approach might have. On paper, and deep into the motivations of many heritage managers, conservation is the goal. For example, the Faro Convention (CoE 2005), is probably the clearest piece of legislation regarding the right to participation and the importance of cultural heritage for society. Still, conservation stays before people and only eight (mostly Balkan) of the score of European countries included in the project have ratified it to date. Italy is probably the biggest player in the field (among 
the signatories of the Convention), but the actual application on paper and practice is, at least, questionable (Benetti and Santacroce 2019). Despite the contradictions, almost every country is already applying some degree of participation, mainly fostered from research interventions (academic archaeology), but with an increasing action from private initiatives too. The problem is maybe in the limited reach of the current situation. A people-centred approach is not only about communication or participation, but about considering the consequences of archaeological heritage management for people, trying to improve social issues while preserving archaeological heritage (or at least trying not to aggravate them).

Furthermore, the structural precarity of archaeology should also be central in this approach and considering as fundamental the orientation of our work towards greater (people centred) values (wellbeing, sustainability, etc.), not forgetting we are people as well, and mending the system is a priority in this venture. It is difficult to work securely towards these goals without addressing the discipline first. Again, I have to make clear my call is not against traditional archaeology, but the inclusion of these perspectives as tangential to the core of the discipline. This brings us back to the fundamental values of public archaeology and one of our pending subjects (Almansa-Sánchez 2018).

Structural changes are usually difficult to achieve. However, most of the actions we can take depend exclusively on collective commitment. Now, would the political (and economic) implications of certain steps to be taken resist the weight of powers we have? Returning to the romance of an ideal archaeology that we are failing to realise, and given the latest political moves throughout the World I doubt it. This does not mean archaeology is at risk (or not more than ever), but that we need a unite collective and clear communication strategies in order to convince. A battle for the narrative that overcomes traditional discourses against archaeology (those who stop development, just four stones, treasures and market, etc.), highlighting the potential benefits of a sustainable practice in line with greater intertwined movements like urbanism (e.g. Lefebvre 1968; Harvey 2013), ecology and circular economy (e.g. Korhonen, Honkasalo \& Seppälä 2018; Read \& Alexander 2020), or a broader social justice (critically engaging already existing agendas from human rights to daily politics). Only then we might achieve the relevance we claim and overcome some of the structural challenges we face.

Anyhow, the preliminary conclusions from the project do not offer a very optimistic perspective and this can be read as a call for attention. If now we are openly acknowledging the importance of contemporary society for archaeology, even if just as mere consumers of the heritage we produce, it is time to embrace public archaeology and start a truly structural transformation of our practice. 


\section{References}

AlmansA-SÁNCHEZ J., 2014. Arqueología pública y gestión del patrimonio. Condenados a encontrarse. Debates de Arqueología Medieval 4: 11-28.

Almansa-SÁnCHEZ J., 2017. Arqueología y Sociedad: Interacción y Acción desde la Teoría Crítica. Madrid: Universidad Complutense de Madrid. [PhD dissertation]

AlmANSA-SÁNCHEZ J., 2018. New paths for the future of public archaeology? Cuadernos de Prehistoria y Arqueología de la Universidad de Granada 28: 197-209. DOI: https://doi.org/10.30827/cpag.v28i0.8482

AlmANSA-SÁNCHEZ J., 2020a. A bibliography of public archaeology and archaeological heritage management in the Mediterranean. DigitalCSIC. DOI: http://dx.doi.org/10.20350/digitalCSIC/12720

AlmANSA-SÁNCHEZ J., 2020b. Spaces for creativity in Mediterranean Archaeological Heritage Management. Advances in Archaeological Practice 8(1): 275-287. DOI: https://doi.org/10.1017/aap.2020.21

ALMANSA-SÁNCHEZ J., forthcoming. Hard times to plan: Challenges to restructure a working plan during the pandemic, and other stories of \#pubarchMED. Archeostorie Journal of Public Archaeology.

BennetTi F. \& SANTACROCE C., 2019. In the public interest? Archaeological research, permits and public participation in Italy. European Journal of PostClassical Archaeologies 9: 169-198.

Burchi B. \& Del Soldato V., 2009. Un Bilancio Sociale per la Parchi Val di Cornia SpA, in LUZZATI, T. \& SBrilli, L. (sds.) Tra cultura e ambiente. Verso un bilancio sociale per la Parchi Val di Cornia SpA. Milano: Il Sole 24 Ore: 122-73.

COE, 2015. Council of Europe Framework Convention on the V alue of Cultural Heritage for Society. Council of Europe Treaty Series - No. 199. Faro: Council of Europe.

Coto-Sarmiento M., Delgado Anés L., López Martínez L., Martín Alonso J., Pastor Pérez A., Ruiz, A. \& Yubero M., 2020. Informe sobre el acoso sexual en arqueología (España). Barcelona, Granada and Madrid: Zenodo. DOI: *https://doi.org/10.5281/zenodo.3662763

Court S. \& Wijesurija G., 2015. People-Centred Approaches to the Conservation of Cultural Heritage: Living Heritage. Rome ICCROM.

Debord G., 1956. Théorie de la dérive. Les Levres nues 9.

DE SALAS J., 1994. Ortega, lector de Nietzsche. Las Meditaciones del Quijote frente a Meditaciones Intempestivas II, in SChonberger, A. \& Zimmermann, K. (eds.), De Orbis Hispani linguis litteris historia moribus. Festschrift für Dietrich Briese $\neg$ meister zum 60 Geburstag. Frankfurt: Domus Editoria Europaea: 877-904.

Evans T.M., Bira L., Gastelum J. B. Weiss, L.T. \& VAnderford N.L., 2018. Evidence for a mental health crisis in graduate education Nature Biotechnology. 36(3): 282-284. DOI: https://doi.org/10.1038/nbt.4089

FAirClough N., 2003. Analysing Discourse. Textual analysis for social research. London: Routledge.

FLEXNER J.L., 2020. Degrowth and a sustainable future for archaeology. Archaeological Dialogues 27(2): 159-171.

DOI: https://doi.org/10.1017/S1380203820000203 
FRITZ J.M. \& PLOG F.T., 1970. The nature of archaeological explanation. American Antiquity 35(4), 405-12.

GOULD F.G., 2019. Empowering communities through archaeology and heritage. The role of local governance in economic development. London: Bloomsbury.

Hamilakis Y. \& AnAgnostopoulos A. 2009. What is Archaeological Ethnography? Public Archaeology 8(2-3): 65-87.

DOI: https://doi.org/10.1179/175355309X457150

HARVEY D., 2013. Rebel cities: From the right to the city to the urban revolution. New York: Verso.

HeNDREN S., 2020. What can a body do? How we meet the built world. New York: Riverhead Books.

HolTORF C., 2005. From Stonehenge to Las Vegas. Archaeology as popular culture. Walnut Creek: Alta Mira Press.

Korhonen J., Honkasalo A. \& Seppälä J., 2018. Circular Economy: The Concept and its Limitations. Ecological Economics 143: 37-46. DOI: https://doi.org/10.1016/j.ecolecon.2017.06.041

Lefebvre H., 1968. Le Droit à la Ville. Paris: Seuil.

Martínez B. \& Querol M.A., 1996. La gestión del Patrimonio Arqueológico en España. Madrid: Alianza.

Marx A., Nurra F. \& Salas-Rossenbach K., 2017. Europeans \& Archaeology: A survey on the European perception of archaeology and archaeological heritage. Paris: Inrap. DOI: https://dx.doi.org/10.5284/1043770

MATSUdA A., 2004. The concept of 'the public' and the aims of public archaeology. Papers from the Institute of Archaeology 15: 66-76.

MCGimsey III Ch., 1972. Public Archeology. New York: Seminar Press.

Moshenska G., 2017. Introduction: Public archaeology as practice and scholarship where archaeology meets the world, in: MoshenskA, G. (ed.), Key concepts in public archaeology. London: UCL Press: 1-13.

Novaković P., Horñák M., Guermandi M.P., Stäuble H., Depaepe P. \& Demoule J.P. (eds.), 2016. Recent Developments in Preventive Archaeology in Europe. Ljublana: Ljublana University Press. https://doi.org/10.4312/9789612378882

Olivier L., 2016. How I learned the Law of the Market, in P. ApAricio (ed.), Archaeology and Neoliberalism. Madrid: JAS Arqueología Editorial: 223-238.

Ortega y Gasset J., 1914. Meditaciones del Quijote. Madrid: Residencia de Estudiantes.

PASTOR-PÉREZ A., 2016. Towards a social archaeological conservation in Barcelona. Complutum 27(2): 259-280.

PotTer P.B., 1994. Public Archaeology in Annapolis. A critical approach to bistory in Maryland's ancient city. Washington D.C.: Smithsonian Institution Press.

READ R. \& AlEXANDER S., 2020. Extinction Rebellion. Insights from the inside. London: Simplicity Institute.

Richardson L. \& Almansa-SÁnChez J., 2015. Do you even know what Public Archaeology is? Trends, Theory, Practice, Ethics. World Archaeology 47(2): 194-211. 
SCHADla-Hall T., 1999. Editorial: Public Archaeology. European Journal of Archaeology 2(2): 147-58.

WATSON S., 2021. Archaeology and public Benefit. EAC symposium proceedings. Internet Archaeology, 57. DOI: https://doi.org/10.11141/ia.57.19

ZorZIN N., 2015. Dystopian Archaeologies: the Implementation of the Logic of Capital in Heritage Management. International Journal of Historical Archaeology 19: 791809.

ZORZIN N., 2021. Is archaeology conceivable within the degrowth movement? Archaeological Dialogues 28(1): 1-16.

DOI: https://doi.org/10.1017/S1380203821000015 